\title{
Section News / Nouvelles des Sections
}

\section{ROCKY MOUNTAIN}

The CIF-RMS winter technical session was held on February 1, 2002 in Calgary. The theme of the session was "Historical Sites, Wildland Parks, Forest Land Use Zones \& Recreation Issues Relating to Industry, Government, \& User Groups." Calgary was the ideal venue for this topic, given the various competing land uses and issues in the eastern slopes of the Rocky Mountains west of Calgary.

Dean Wentzel of Alberta Community Development discussed the Historical Resources Act and the need to protect historical resources (i.e., artifacts, native burial sites) in forestry and oil/gas operations. Where historical and archeological sites in Alberta's forests have been identified, they are protected through land use protective notations, which industries have to consult in the planning phase of operations. The key concern is to proactively plan for protection of sites that have not yet been identified. The department has worked closely with Millar Western Forest Industries of Whitecourt to develop a process to integrate historical resources planning into forest management planning. This involves identifying areas of high to low historical resource potential (e.g., along watercourses), and conducting more detailed assessments of high potential areas in more detailed plans. The oil/gas industry is also doing assessments in siting reports, which are submitted to government in the early phases of development planning.

Doug Bowes of Parks and Protected Areas, Alberta Government, discussed the various protected area designations in Alberta and ideas for protection adjacent to these. Many Wildland Provincial Parks have been designated recently through the "Special Places 2000" program in Alberta, most notably in the eastern slopes near Kananaskis Country. Doug discussed how many of these areas are "disconnected" and that to maintain a seamless ecological transition between the "working forest" and protected areas requires dialogue between all users. $\mathrm{He}$ noted recent positive discussions between a forest company and the parks department which resulted in timber harvest plans adjacent to new protected areas that retained structure, minimized disturbance to soils and road building adjacent to the protected area. The overall objec-

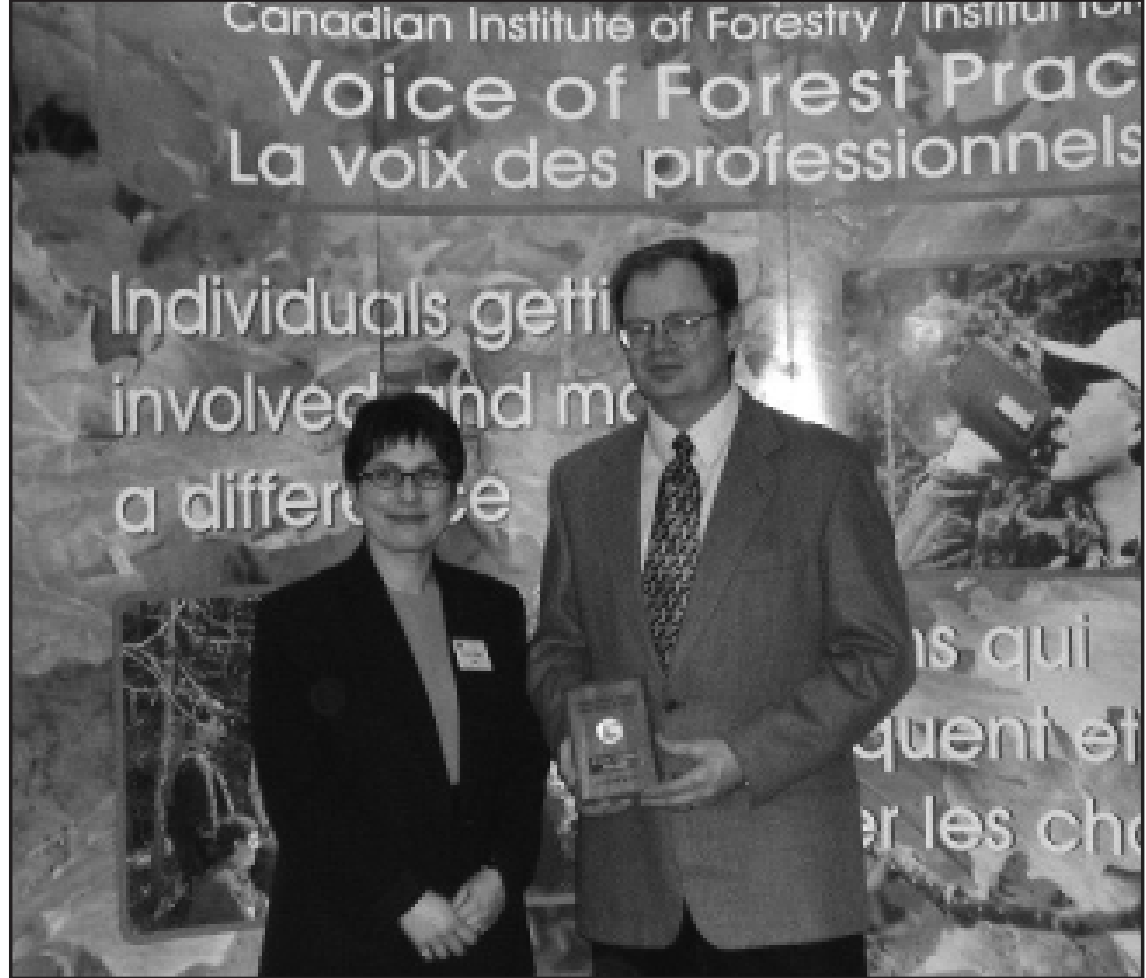

Herman Stegehuis, University of Alberta, receives the CIF Gold Medal from Teresa Stokes, Chair, RMS.

tive is to avoid having protected areas becoming isolated "ecological islands."

Stephen Ferdinand of Sustainable Resource Development, Alberta government, outlined the Forest Land Use Zone designation which is possible under the Forests Act of Alberta. The FLU is established in regulation and can be a useful tool in resolving conflicts in areas of high competing land use. They outline very specific regulations about activity restrictions in different geographic regions. Some specific competing uses they address are hiking, motorized vehicles (motorcycles, $4 \times 4 \mathrm{~s}$ ), and horseback riding. Examples include the Maclean Creek and Panthers Corners Forest Land Use Zones. Such designations have to be based on a plan for specific use of trails, etc., based on extensive consultation with local public interests.

Rick Blackwood, Forest Area Manager of Sustainable Resource Development for Calgary, outlined the issues relating to present policy and conflicting uses of public land. Rick discussed how many policies regarding integration of land use in the eastern slopes of the Rocky Mountains are outdated. Some key changes that have occurred since the eastern slopes policies were developed in the late 1970's. Perhaps most significantly, there has been a drastic increase in the population in and around Calgary (almost double since late 1970). This has resulted in a dramatic increase in the number of users of public land west of Calgary. In addition, different types of recreation have developed, which were not anticipated in the original east slopes policy. These include rock/ice climbing, mountain biking, quading, and increased $4 \times 4$ activity. People are also taking to the forest to conduct "rave parties" which are frowned upon in the city! The issues that need to be addressed in an updated policy include access management, public safety (e.g., with remote rock climbing), environmental damage ( $4 \times 4 \mathrm{~s}$, quads), and enforcement.

Representatives from recreational user groups briefly outlined some of their concerns with the increased level of activity on public lands in the east slopes. 
Vince D'Eon of the Alberta United Recreationalist Society discussed how motorized users want to retain access to the forests, and this requires good government rules and enforcement of the "bad actors." Sandra Foss of the Federation of Alberta Naturalists discussed concerns about the level of oil/gas activity and the need to minimize impacts to the forest.

Increasing population and greater numbers of people who utilize the forest challenge resource managers to develop innovative solutions to minimize conflicts. Some options include land use designations, updated policies and regulations, new integrated planning processes, and most significantly, extensive dialogue amongst the competing interests.

\section{Scott Milligan CIF/RMS Councilor}

\section{Mr. Gerald (Gerry) K. Seed, CIF 50 Year Golden Member}

Gerry was born in Fort William, Ontario, which is now Thunder Bay. He grew up in a community called Black Hawk near Fort Frances, Ontario, and went to grade 10 in a one-room school house and then to high school in Fort Frances.

At age 16, Gerry joined the armed services and served a little over two years in the Air Force and the Canadian Army as the war was ending. As a result of an early work history in the woods, Gerry decided to seek out a career in forestry. He received a Bachelors degree from the University of New Brunswick in 1950 and a Masters degree from the University of Minnesota in 1951.

Summer employment during University involved timber cruising and regeneration surveys with the New Brunswick International Paper Company in the Gaspé, The Ontario Paper Company at Hemlo and The Ontario-Minnesota Pulp and Paper Company at Kenora.

Following graduation, Gerry's employment was as follows:

- 51/2 years with the Ontario-Minnesota Pulp and Paper Company in forest investigations then as assistant logging superintendent.

- 91/2 years with Dryden Paper Company in logging operations and wood handling operations at the mill.

- 26 years with Great Lakes Paper Company, which later became Canadian Pacific Forest Products, as Development Engineer, Manager of Development and

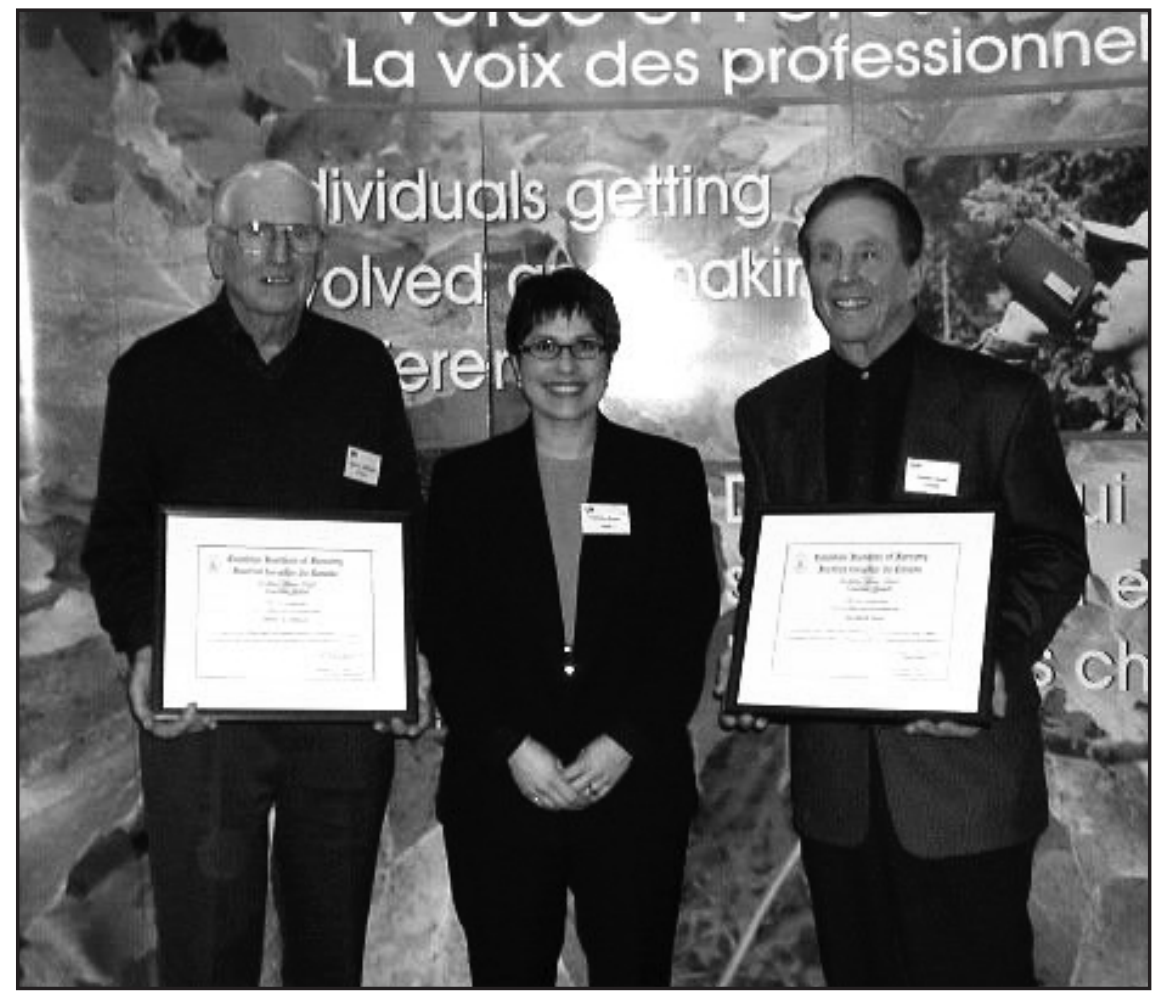

Teresa Stokes presents 50-year membership certificates to Harry Johnson (L) and Gerry Seed $(R)$.

Engineering, Manager of Production, Manager of Woodlands Operations and finally as Regional Vice President of Woodlands Operations for Thunder Bay and Dryden.

Over the years Gerry was heavily involved in the mechanization of woods operations.

Gerry was also very active serving on various Association Boards; he was: - Involved in the early forestry group which became Lake of the Woods Section of the CIF

- Chairman of Lake of the Woods Section

- Chairman of the Logging Operations Group, Canadian Pulp and Paper Association

- Chairman of the Central Section, Canadian Pulp and Paper Association

- Chairman of the Woodlands Section, Canadian Pulp and Paper Association

- Chairman Ontario Forest Industries Association

Gerry has been married to Iola for 54 years. They have two sons and a daughter and four grandchildren. He is enjoying his retirement in Alberta with regular visits to the home area in North Western Ontario.

\section{Speech by Gerry Seed}

Chair Teresa and Section Members I want to thank you for having me out to lunch today and for the presentation. With the change in lifestyle that came with retirement in 1991, I rarely meet with people of the profession. Life has become family, summers at the farm in North Western Ontario and winters downhill skiing five days a week at home here in Calgary.

Fifty years, a whole half a century, seems like a very long time but let me tell you it goes by quickly and even seems to speed up after retirement. My advice to you is to make the most of all aspects of life as you go along.

Younger people generally ask about the changes that have taken place during that long period of time and I will comment briefly on a few that seem important to me.

1. Foremost, there has been tremendous improvement in regenerating the forest. In the early days, this was mostly experimental. Now with harvesting at or near the allowable cut, it has become a major part of operations.

2. Today there is much emphasis on care of the environment whereas in the early days, the emphasis was on opening up forest areas and creating work. 
3. Over the years, there has been a tremendous increase in research in all aspects of forestry and pertaining to specific areas of the country. In the early days, there was very little and it was mostly carried out by the Dominion Forestry Service, the provincial governments and a few dedicated foresters.

4. In logging operations, there has also been change: change from manual to mechanized harvesting, change in wood delivery from water and rail to truck, change in operations from company to contractor and from camp to commuter.

I know there have been many other changes but to me, these are the outstanding ones.

Now, on the lighter side, I'd like to share with you a couple of memories from my early days of camp life. These occurred in what was known as the East Patricia Limit out of Kenora. Here there were several outlying camps reporting to a headquarters camp where 70 families were housed as well bunkhouse and kitchen facilities for the single workers. The buildings were $2 \times 4$ frame covered on both sides by a paperboard called Insulite. One morning I got a call from a French foreman at one of the outlying camps. The message went something like this "De bear she got into de kitchen. She at de 15 blueberry pie and left the mince."

My wife and I lived in one of the family houses at the headquarters camp. There were no indoor facilities in these houses, so for emergencies we had to keep a little container under the bed. This, of course, had to be emptied every morning in the little house out back. To help pass the time away on those long winter evenings, my wife and I used to play cribbage. It was the only card game I ever heard of where the loser took the pot.

Again, I want to thank you for have me out to lunch and for your thoughtfulness in presenting me with this certificate and to each and every one of you, my best wishes in your forestry career.

\section{Are You Moving?}

Please help us to keep our records up to date. Let us know when your address changes. There are four ways to tell us:

1. Email us at cif@cif-ifc.org

2. Fax us at (613) 234-6181

3. Telephone us at (613) 234-2242

4. Mail us at 151 Slater St., Suite 606, Ottawa, ON k1P 5H3

\section{SOUTHERN ONTARIO}

\section{Section Meeting}

Deep within the confines of an urban forest ecosystem (trees, ravine forests, rooftop tree groves, people, squirrels, dogs, raccoons, etc.) an impressive number (one of us lost count at 43) of forestry practitioners met. It was the Southern Ontario Section's January 9 meeting, at the University of Toronto's Earth Sciences Centre, where we explored the role of forestry practitioners in a relentlessly changing Southern Ontario landscape. The program was moderated by Andy Kenney, head of the U of T's Urban Forest Centre, a CIF member, the coordinator of the Federation of Ontario Naturalists, and the President of the Ontario Urban Forest Council (formerly the Ontario Shade Tree Council).

Bruce Ferguson, Chairman of the CIFSOS, spoke of the CIF as the voice for Canadian forestry and for quality forest practices and practitioners, within our diversified southern Ontario landscape. Here, CIF will be concerned with how we, as professional resource managers, can contribute to optimizing the considerable flow of material and other forest products, the contribution of the forest to quality of life, and the perpetual need for research. As commented on by Bruce, there will be growth in manufacturing and employment, with great scope to expand over the next decade or so. Though this comment sounds encouraging, one member asked the question: "how do we ensure that our forest is big enough, healthy enough and properly located and managed to meet the full potential to satisfy all this?" CIF might help by working for land use policy change; public awareness; lifelong learning and adaptive management; innovation; positive progress; supporting research, education, training; encouraging productive healthy forestry; safeguarding our landscape heritage; and promoting a "forest accord" of NGO's and others who share our passion for southern Ontario forest sustainability.

Rick Monzon, the executive director of the Ontario Professional Forestry Association, described the changing role and responsibility of R.P.F.'s in the province as one of registering professional foresters and regulating their practice. There will be mandatory continuing education, monitoring and peer review, consistent with increased provincial regulation and to balance public and private interest. Mack Williams states, " this comes at a time of increased municipal interest in areas like tree cutting by-laws and increased municipal activity in safeguarding nature in its planning and other activities." Increasingly there is a need for professionals with balanced views of all aspects of natural systems, with a growing range of expertise, who are able to communicate well, are accountable, and can be people of vision. Rorke Bryan, Dean of Forestry at U. of T., in his welcome, noted forestry and forestry education are at a crossroads in Canada and abroad. In dialogue with other Deans worldwide, Mr. Bryan concluded declining enrolment into forestry schools is widespread, while at Toronto this is trend is reversed. Is there renewed public forestry interest in southmonitoring of professionals, and a need

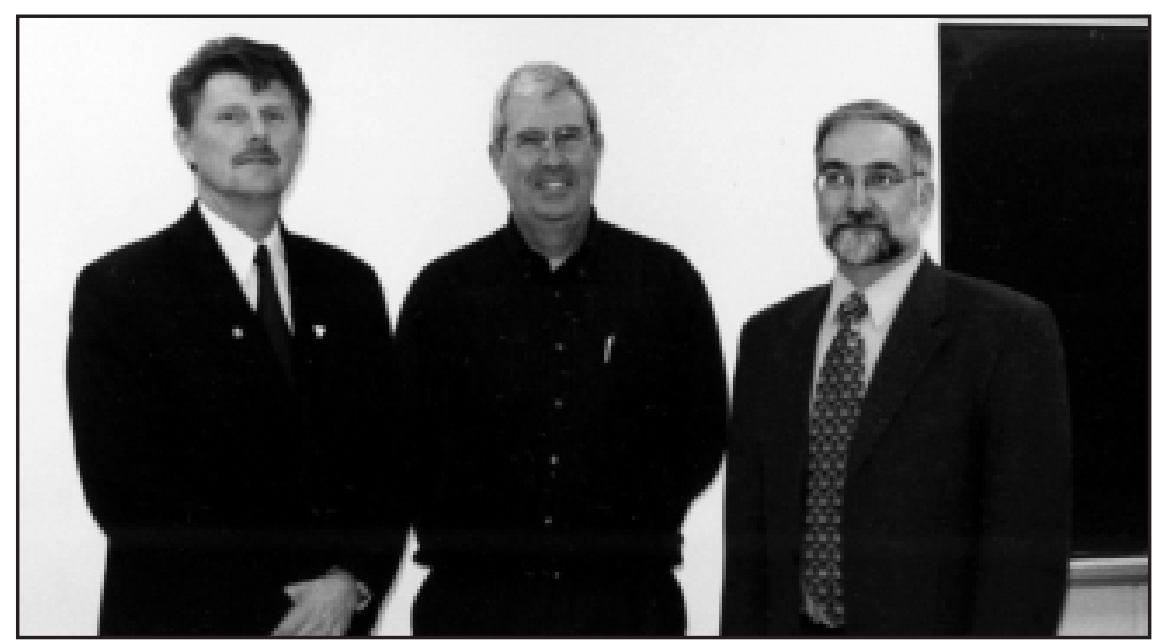

CIF-SOS Forestry Talk Speakers (L to R): Bruce Ferguson (Section Pres.), Rick Monzon (Exec. Dir. of the OPFA), and Andy Kenney (Pres. of the Ont. Urban Forestry Council). 


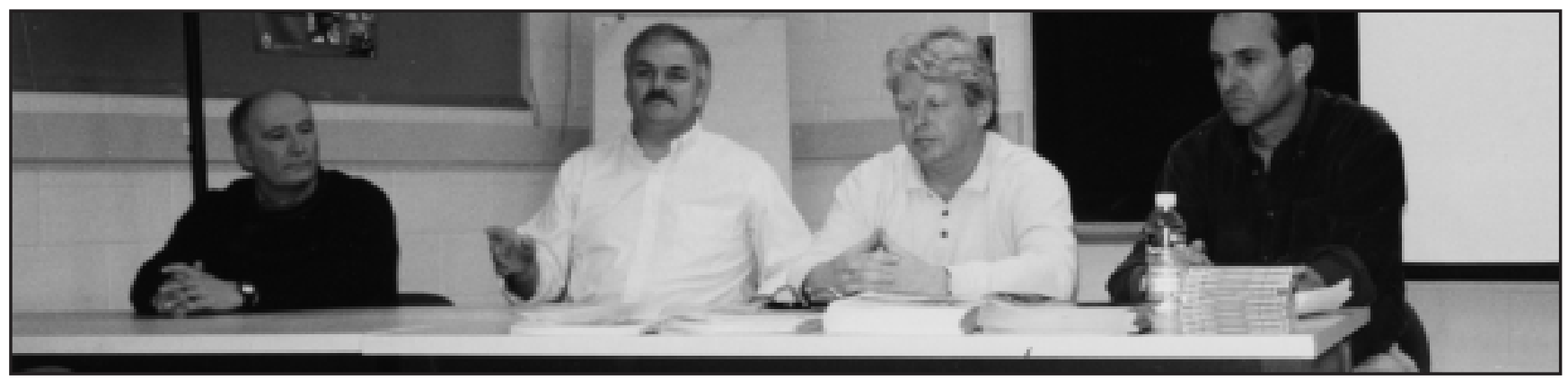

Panel members (L to R): David Devillers (Landowner), Earl Dertinger (Stewardship Coordinator - North Simcoe), Jim Faught (Exec. Dir. of FON), and Eric Boysen (Private Land Policy Advisor - OMNR).

ern Ontario? Is the fact that some 500 delegates attended the "Woods Talk" at the FON conference last summer in Toronto any indication of people's interest or quiet commitment in supporting forest ecosystems? How does this translate to attracting young, energetic minds to pursue a forestry education?

The afternoon session was initiated by Jim Faught, R.P.F. and Executive Director of the FON. The FON operates a major education program in conservation of nature, with numerous publications available, including an education kit for teachers. For some years FON focused on improving conservation of wetlands with a recent shift to include woodland areas. Woodland conservation was the theme for the 2001 annual conference located at York University. Within the woodland conservation strand, FON possesses a number of publications, one of a CD-ROM with the proceedings of the 2001 conference talks coupled with the conference held at Trent University in 1999. FON's quarterly magazine, Seasons, has a circulation of 10000 and reaches an estimated 100 000 readers. On an additional note, FON is attempting to enlarge on the "Big Picture" idea set by resource managers attached to the Carolinian zone and the Eastern Ontario Model Forest groups. Jim notes about $15 \%$ of the North American landscape is under some type of protection, yet this, for example, is of limited use to wildlife since all the bits and pieces have yet to be well connected. Jim states "FON is examining what is required to complete the bigger picture, be it corridors, policy, or whatever."

Following Jim Faught's presentation, Earl Dertinger, stewardship coordinator for North Simcoe, spoke inspiringly of the make-up and role of the stewardship council. There are 40 coordinators, and between 500 and 600 volunteer council members seen by Earl as leaders of communities. Earl spoke strongly on the value of bringing together as many people and organizations as possible in some form of partnership or alliance, and of developing political support. Some points he stressed were 1) Informed decision-makers are imperative, 2) An immense need exists to manage our dwindling timber resources wisely, 3) Public education of good forestry practices and its benefits must be communicated to all, 4) Educating woodlot owners on the value of their timber resources, and the extended economic, social, and environmental values is required, 5) North Simcoe stewardship council has accomplished tasks that would not happen if the partners worked just as hard but separately, and 6) The North Simcoe group has made great efforts integrating all volunteers for projects. Earl states that the North Simcoe stewardship council has three objectives: 1) Enhance stewardship, 2) Help owners plan and do good things, and 3 ) Improve coordination among all interested parties.

The role facing professional forestry practitioners is ever evolving and challenging, with possible risks and rewards.

Tony Molnar, R.P.F., Communications Councillor. Mack Williams, R.P.F., Editor.

\section{Errors and Omissions Insurance for CIF/IFC Consultant Members}

CIF/IFC Errors \& Omissions policy administered by LMS Prolink Ltd. Insurance Brokers will provide you with coverage for third party legal liability resulting from an actual or alleged error, omission, or negligent act for: Financial Loss and your Legal Costs.

For more information: please contact Rick Barnard C.A., CAIB at 416-5957484 or 1-800-663-6828, email: rickb@lms.ca. For an application form, please contact the CIF/IFC National Office at Tel : 613-234-2242, Fax: 613-234-6181, Email: cif@cif-ifc.org

Group Benefits plan for CIF/IFC Members:

CIF/IFC is pleased to provide a group benefits plan to their members. The plan is underwritten by LMS Prolink Ltd. It offers:

- Life Insurance and Accidental Death and

Dismemberment Benefits

- Weekly Income Benefit

- Long Term Disability Benefit

As well as optional Member Dependent Benefits:

- Member Assistance Program "Connections"

- Extended Health Care

- Dental

For more information, please contact LMS Prolink Ltd. 1-800-663-6828, 416595-7484, email info@lms.ca 


\section{OTTAWA VALLEY}

On the evening of Wednesday January 16, 2002, the OV Section presented an evening of presentations and discussions of the XII World Forestry Congress 2003, "Forests, Source of Life", Quebec, September 21-28, 2003.

Wendy Ripmeeseter chaired the evening, and introduced the panelists, Jean-Louis Kerouac, Dr. Yvan Hardy and Roxanne Comeau.

M. Jean-Louis Kerouac, Secretary General, XII World Forestry Congress 2003 spoke on the congress and its theme "Forests - Source of Life." This will be the largest forestry congress ever and the largest held in Canada. About 5000 participants are expected to attend.

Dr. Yvan Hardy, Assistant Deputy Minister, Canadian Forest Service, outlined the efforts to have the congress convene in Canada. The congress will:

- Provide an opportunity to showcase Canada's forestry achievements.

- Mobilize the Canadian forestry community to be active and participate.

The CFS involvement/challenge is to ensure a significant Canadian content in the program, including government, industry, education and forestry communities. The Congress will be a unique occasion to showcase what Canada is doing through papers, displays and the media.

Ms. Roxanne Comeau, Executive Director, Canadian Institute of Forestry, indicated how the congress fits within the role and objectives of the CIF. The Congress will provide an opportunity to promote public awareness of forestry, showcase the National Forestry Strategy, and promote the role of forestry parishioners. Challenges include:

- How to make forestry a priority on the world agenda.

- Making the congress relevant

- Implementing changes as a result of the Congress

Ms Comeau encouraged CIF members to work in various capacities to make the Congress a success and to promote the early submission of papers.

The texts of the three presentations appear elsewhere in this edition (National News).

Lorne Riley, Brian Barkley, Roxanne Comeau and Brian Haddon presented the CIF's Tree of Life Award (certificate and pin) to John H. Sellers, R.P.F. The Tree of Life Award is a nationally recognized award, selected and awarded by a section to individuals who have made superior,

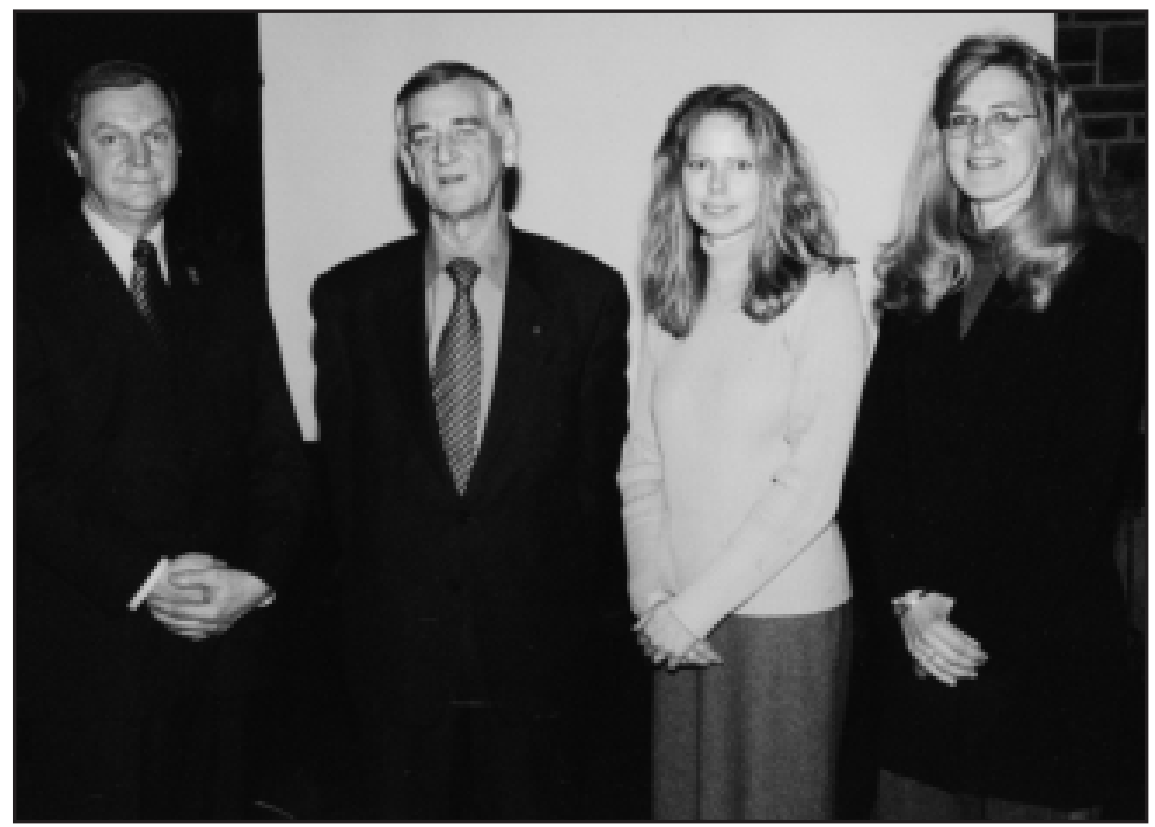

L to R: Jean-Louis Kerouac, Dr. Yvan Hardy, Wendy Ripmeester, Roxanne Comeau.

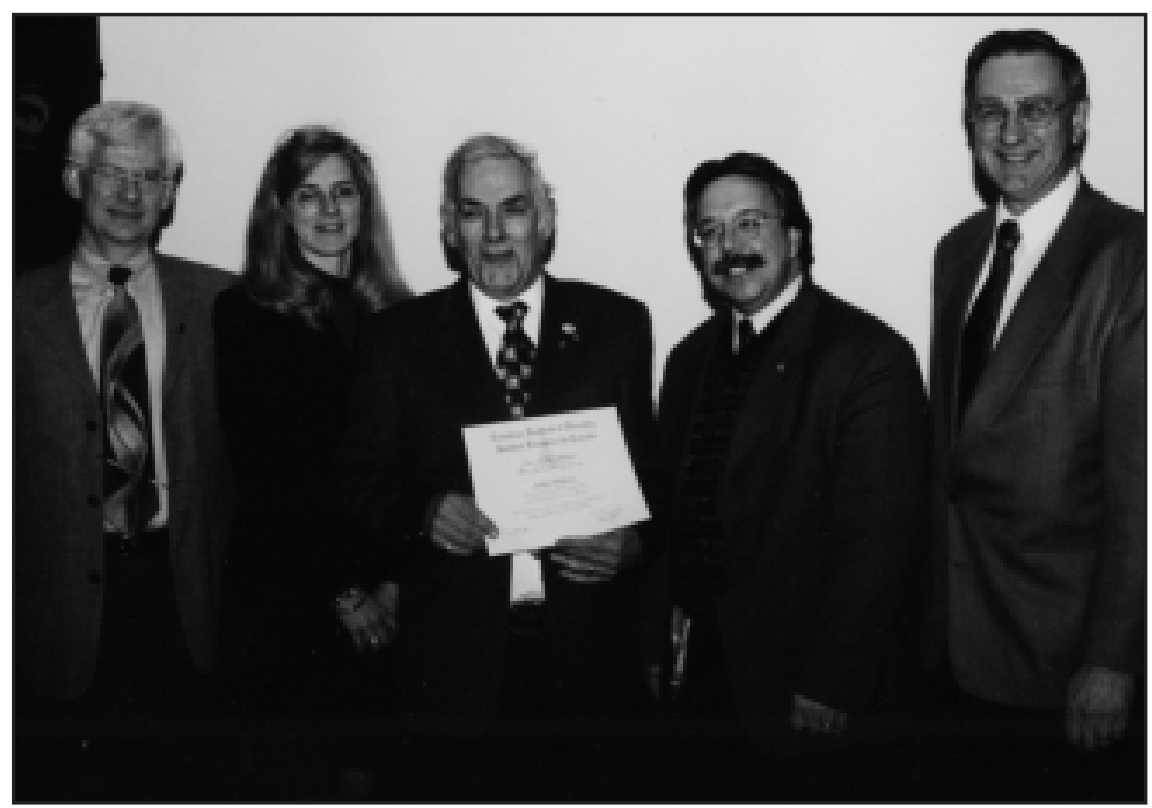

Tree of Life Award presented to John Sellers. L to R: Brian Haddon, Roxanne Comeau, John Sellers, Brian Barkley, Lorne Riley.

dedicated or particularly effective contributions to sustainable forest resource management, forest renewal or sustained yield integrated management of the forest and its intrinsic resources. This also recognized the many contributions to the section and the practice of forestry in Ontario (see also "Personals" in this edition). 